after her first confinement. The patient was somewbat a riæmic, but otherwise looked well. She was able to move about briskly and was free from breathlessness. On examination of the heart the apex beat was found to be somewhat prominent, but in its normal position. The heart sounds were clear and rather accentuated, about eighty-five in the minute. $A$ well-marked blowing murmur was heard in the fourth interspace about one inch from the left border of the sternum. It distinctly followed the first sound, and appeared to run up to the second sound, an interval occurring between the first sound and the murmur. The point of maximum intensity of this post-systolic bruit was at the place indicated, and it was well heard beside the sternum, but not at the base, and was scarcely audible at the extreme apex and not at all outside of it. At the end of a deep inspiration the murmur was absent. It disappeared after treatment by rest and arsenic.

CASE 4.-This patient, a married woman aged fortyone years, had been an invalid for some years. Fifteen years before she came under observation the ovaries were removed for tubal disease. She bad not menstruated since the operation. She suffered much from palpitation and nerrousness. 'The pulse was regular, jerky, 100, even when lying in bed. The area of the cardiac impulse was increased, and the whole of the precordial region heaved more or less with the systole. The extreme apex was behind the fifth rib three inches from the left borcler of the sternum. Notwithstanding the excessive impulse the cardiac dulness was slightly, if at all, increased. On auscultation at the extreme apex the sounds were very loud and "membranous," and a short blowing murmur accompanied the first sound. This was best marked towards the termination of the sound and increased in intensity as the sternum was approached, where it became musical. It was audible as high as the third interspace as a musical sound, but was merged in the second interspace in a soft blowing murmur (hæmic). At the end of a full breath it was much diminished, and it was greatly exaggerated when the patient lay on her right side. It was not andible to the left of the apex. At times when the patient was free from excitement the murmur was entirely absent.

CAst 5.-A boy, aged twelve years, with a nerrous history, often had attacks of the nature of hysteria. He complained of giddiness and some shertness of breath on exertion. He had never had rheumatism. On examination of the heart there was a tamultuous hearing impulse. The apex was a little below the normal position; there was no thrill. A lond, short, systolic murmur could be heard to the left of the sternum. It was best marked about the fifth rib and was not audible at the immediate apex. There were no basic murmurs. The heart beat was 1:0, jerky and regular. The murmur became much more localised after resting, eren though the number of heart beats was not reduced to any extent. On drawing a deep breath the murmur was absent at the end of inspiration. On lying on the right side the murmur was first intensified by the movement, but after a few minutes disappeared altogether.

CASE 6 -A man, aged twenty-nine years, had suffered from cough, night-sweats, and some emaciation for three or four months. He was highly nervous and somewhat short of breath. The right chest was flat beneath the clavicle, where the note was relatively dull. When standing, a loud, short, diastolic murmur could be heard to the right of the sternum. The point of maximum intensity was just above the right nipple, but it was andible from the clavicle to the fifth rib. Toe heart beat was jerky and nervous (120 in the minute), but after ten minutes' rest came down to 90 and the murmur disappeared. It also disappeared on the patient drawing a long breath and holding it. Over the same area a well-marked systolic cardio respiratory murmur was heard during a quiet deep inspiration, but this was quite distinct from the sound already referred to. The pulse was small and rapid, but not suggestive of Corrigan's.

CASE 7.-Another case, closely resembling the above, was that of a man, aged thirty-eight years, who was admitted into the Royal Infirmary, Newcastle, in December, 1886, for cough and hæmop'ysis. There was some retraction of the right lung and evidence of early phthisis. There was a short, whiffing, early diastolic murmur which terminated abruptly in the second sound. It was best heard between the apex and the sternum along the fifth interspace. It was loud on excitement, but disappeared on resting or on holding the breath.

CASE 8.-A man, aged twenty-nine years, of habitually nervous tendency, had complained for upwards of three years of a pain about the left nipple, which he ascribed to his heart. He had frequent attacks of palpitation with a feeling of intense apprebension of approaching danger, when he trembled all over. The pain was worse at night. The heart was rapid, 100 in a minute when standing. The lef apex beat was in the nipple line between the fifth and sixth ribs. In the erect posture a loud, systolic, blowing murmur was heard at the apex, beyond which it was not conducted, being limited to within a narrow circle at this point. This murmur was intensified on drawing a long breath, and was increased in loudness as the inspiration reached its termina tion, but on holding a very long breath it disappeared. After lying down for a few minutes it was no longer audible.

A few points stand out prominently in connexion with these mimetic murmurs: firstly, they occur in highly neurotic people; secondly, they are frequently associated with vio. lently acting ventricles independent of lung conditions thirdly, they may be intimately connected with respiration and structural alterations in the lungs; fourthly, they are not limited to any cardiac area; fifthly, they may be sys tolic, post systolic, or early diastolic ; and sixthly, they can be diagnosed by an appeal to certain tests, chiefly rest, position, and respiratory movements. (See table at end of first paper, THE LANCET, July 27th, 1895, p. 196).

Newcastle-on-Tyne.

\section{A CASE OF PHTHISIS COMMUNICATED FROM HUSBAND TO WIFE.}

BY WILLIAM MURRELL, M.D., F.R.C.P.,

LECTURER ON PHARMACOLOGY AT THE WESTMINSTER HOSPITAT.

A WOMAN, aged thirty-six years, was admitted into the Westminster Hospital suffering from phthisis. Both her father and mother were alive and well, and she had three sisters and one brother all grown up and in good bealth There was no history of phthisis in her family cn either side. Her husband was apparently healthy when she married him, but his father and one sister died from phthisis. After a time he developed a cough, spat blood, and ultimately died, it being stated on the certificate that the cause of death was phthisis. During the last seven months of his life he was too weak to go out, and his wife nursed him incessantly. They had only one small room, and the fire was kept burning day and night. He expectorated a great deal, and no directions were given her as to the use of antiseptics. Soon after his death she noticed that she had a bad cough, and when she came under observation it was found that she had cavernous breathing with whispering pectoriloquy at the right apex and dulness and crepitation at the left. She stated that she was no worse off in consequence of her husband's death, but that, on the contrary, her means had improved, as during her husband's illness she had to keep him.

Remarks. - This case is of no particular interest in itself but it is so when taken in conjunction with similar cases recorded in THE LANCET of May 22nd, 1880, and a similar series of cases published by Dr. Reginald Thompson in THE LANCET of Nov. 6th of the eame year, as marking the change of opinion respecting the contagiousness of phthisis which has taken place since that time. Sixteen years ago such cases were regarded with suspicion and their publicaticn excited hostile criticism ; now they are so common that they excite but little comment. Dr. Hermann Weber ${ }^{1}$ gave details of thirty-nine wives who became infected from marrying phthisical husbands, and in several cases the husband infected more than one wife. The reason the husband infects the wife more frequently than the wife the husband is explained by the fact that when the husband is ill the wife nurses him, but when the wife is ill the husband from the increased demands on his resources has to pay closer attention to business and is less at home than usual. In connexion with the subject of the contagiousness of phthisis it is difficult to avoid reference to the risk which is run by healthy people on long sea royages if compelled to occupy the same cabin with patients suffering from advanced phtbisis. The sleeping cars which convey large numbers of phthisical patients to the Riviera and other popular kealth resorts a certain periods of the year are not above suspicion, and much greater care should be taken in having them aired and disinfected than is at present the case.

Welbeck-street, $W$. 